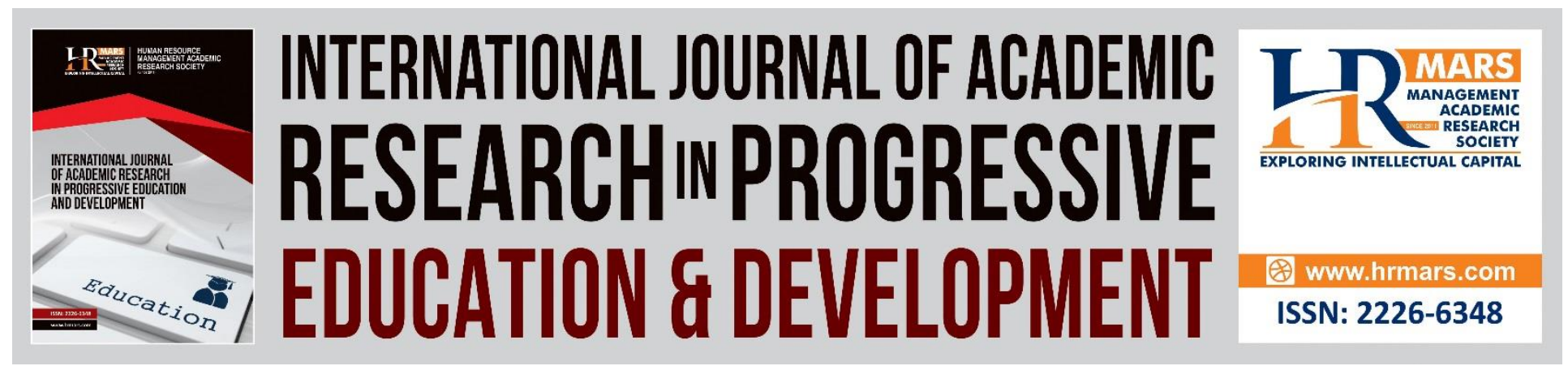

\title{
Information Literacy Development through Resource-Based School Projects: Malaysian Students Experience
}

Halida Yu, Tengku Adil Tengku Izhar, Ezza Rafedziawati Kamal Rafedzi, Norhayati Husin and Wan Nor Haliza Wan Mokhtar

To Link this Article: http://dx.doi.org/10.6007/IJARPED/v7-i3/4360 DOI: 10.6007/IJARPED/v7-i3/4360

Received: 06 June 2018, Revised: 19 June 2018, Accepted: 03 July 2018

Published Online: 26 July 2018

In-Text Citation: (Yu, Izhar, Rafedzi, Husin, \& Mokhtar, 2018)

To Cite this Article: Yu, H., Izhar, T. A. T., Rafedzi, E. R. K., Husin, N., \& Mokhtar, W. N. H. W. (2018). Information Literacy Development through Resource-Based School Projects: Malaysian Students Experience. International Journal of Academic Research in Progressive Education and Development, 7(3), 211-225.

\section{Copyright: (C) 2018 The Author(s)}

Published by Human Resource Management Academic Research Society (www.hrmars.com)

This article is published under the Creative Commons Attribution (CC BY 4.0) license. Anyone may reproduce, distribute, translate and create derivative works of this article (for both commercial and non-commercial purposes), subject to full attribution to the original publication and authors. The full terms of this license may be seen

at: http://creativecommons.org/licences/by/4.0/legalcode

Vol. 7, No. 3, July 2018, Pg. 211 - 225

http://hrmars.com/index.php/pages/detail/IJARPED

JOURNAL HOMEPAGE

Full Terms \& Conditions of access and use can be found at http://hrmars.com/index.php/pages/detail/publication-ethics 


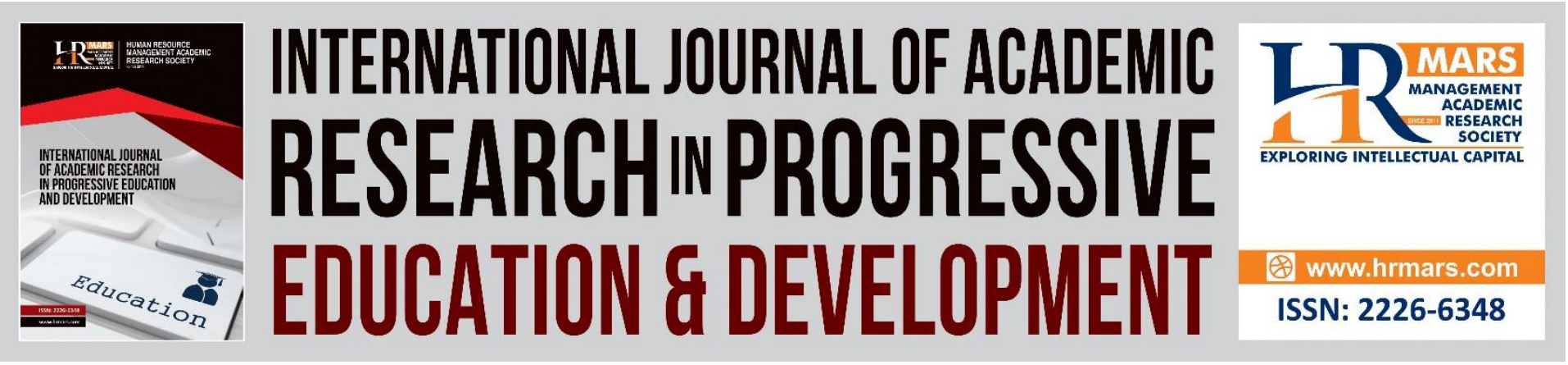

\title{
Information Literacy Development through Resource-Based School Projects: Malaysian Students Experience
}

\author{
Halida Yu¹, Tengku Adil Tengku Izhar2, Ezza Rafedziawati Kamal \\ Rafedzi ${ }^{3}$, Norhayati Husin ${ }^{4}$, and Wan Nor Haliza Wan Mokhtar ${ }^{5}$ \\ Faculty of Information Management, Universiti Teknologi MARA, \\ 40150 Shah Alam, Puncak Perdana Campus, Selangor, Malaysia. \\ Email: ${ }^{1}$ halid917@salam.uitm.edu.my, ${ }^{2}$ tengkuadil4540@salam.uitm.edu.my, \\ 3ezza464@salam.uitm.edu.my, ${ }^{4}$ yatihussin@salam.uitm.edu.my, ${ }^{5}$ whaliza@salam.uitm.edu.my
}

\begin{abstract}
This paper explores how upper secondary school (middle high school) students experience information literacy through resource-based school projects. It aims to understand whether these students have developed improved information literacy competencies after being exposed to various projects during their lower secondary grades. It also examines how, or in which direction of the "Three Directions Model" the students experience information literacy in their project journey. The research participants comprise of a group of seven students from a selected school in Shah Alam, Selangor. The research employs focus group interview data collection technique with the students. The findings show that the students in general have progressed in knowledge and various learning competencies as a result of repeated project work experiences. However, their mastery of fine information literacy skills was still low as information literacy models and literatures were not embedded in their project work instructions. It is recommended that information literacy models be clearly incorporated into project work instructions to assist the students to develop fine and detail information literacy skills. The findings are hoped to provide baseline information on information literacy development in learning contexts where information awareness is still low.
\end{abstract}

Keywords: Information Literacy, Information Literacy Instructions, Secondary Schools, Project Work, Library Science

\section{Introduction}

There has been wide academic interest to produce independent and critical thinking students in the global school education system today. In Malaysia, continuous efforts are also taken by the Ministry of Education (MOE) to produce students in this direction. In the recent years, the 
DEVELOPMENT

Vol. 7, No. 3, July 2018, E-ISSN: 2226-6348 @ 2018 HRMARS

ministry has released Malaysian Education Development Plan (2013-2025) or "Pelan Pembangunan Pendidikan Malaysia 2013-2025, in its effort to produce highly competent school stuents through sound school education system. The new educational plan aims to generate students with higher order thinking skills (HOTS) or kemahiran berfikir aras tinggi (KBAT) through effective school syllabus and programmes, Kementerian Pendidikan Malaysia, (2014).

HOTS are components of the broader information literacy skill. It is not easy to discus information literacy skill in the Malaysian school context as the "information literacy" term is not formally or widely used in the Malaysian school education system. The term is not presented in various MOE's main policies, reports, and documents as reported by Chan (2002), Yu.et. al (2011), and $\mathrm{Yu},(2014)$. Chan, a team member of the Malaysian Smart School Pilot Project, writes:

"information literacy is an important concept in the Smart School Conceptual Blueprint, but the term is not formally presented anywhere in the document".(p. 204).

The inadequate positioning of information literacy in school systems is also experienced in other education systems, as discussed by Hart, (2000) and Tan and Theng, (2006). This is because information literacy is probably one of the most confused or least understood skills in the contemporary world, Jackson, (2006), McAdoo (2008). As a result to this, information literacy is also interchangeably used to address a number of skills such as; library skills, IT skills, electronic searching and information retrieval skills, and critical and creative learning skills; Kuhlthau (1999) Montgomery, 1997; and Tan and Theng, (2006).

The emphasis on information literacy has become more important in the Malaysian school system with the current emphasis on HOTS. This is despite the fact that information literacy is not directly presented in school syllabus. In the context of this study, information literacy is viewed as an umbrella term to include electronic searching and information retrieval skills, library skills, media skills, research skills, reference skills, learning skills, and study skills Montgomery, (1997), Yu, (2014). It is used to represent HOTS skills throughout the discussions. The MOE has been increasing efforts towards generating students with strong HOTS through authentic learning and alternative learning assessment, such as project works. This is in contrast to the previously examination-based learning assessment system.

A broad body of literature demonstrates that project-based learning (PBL) improves student achievement through the development of information literacy and research skills (Chen and Huang, 2014; Ott, 2015; Yu, 2014). The researchers justify that the PBL methodology challenges the students to think critically as they have to reflect on what they have learnt and apply a set of competencies such as problem-solving, decision makings, analysing, and synthesizing information. In Malaysian secondary schools, all lower secondary (middle high) school students (form one to form three) are assigned to work on project works through resource-rich subjects such as history and geography. This means, every student in the lower secondary school has three years of experience working on two projects (history and geography projects) each year for three years in a row. The MOE aspires that through the project experience, students will develop crucial HOTS and other learning skills that are crucial to become competent lifelong learners in this millennial, Kementerian Pelajaran Malaysia, (2006). The ministry justifies that unlike standard 
Vol. 7, No. 3, July 2018, E-ISSN: 2226-6348 @ 2018 HRMARS

examination assessment, project assignments use more holistic assessment approach to evaluate students' overall competency level as students are assessed not only in terms of academic, but also in terms of creativity, talent and initiative, which are reflected through their final project report. Other intrinsic values that can be revealed through these projects are in terms of punctuality, validity and reliability of information, neat and cleanliness of work, responsibility, and collaboration in completing the task, all of which are proven to be almost impossible to assess through the regular written test. (Kementerian Pendidikan Malaysia (2002).

This study aims to investigate how upper secondary (form four) school students in Malaysia understand, and practice information literacy to find and use information through resourcebased project work. The students were traced back one year after they have completed their standardized project work during their final year of lower secondary education to find out their latest information literacy development. This study aims to understand how the students have developed their information literacy mastery (information seeking and use) after completing their lower secondary school education through their descriptions of their current project work experiences. Employing Situated Cognition theory viewed through the Three Directions Model, this study is a follow up study of Yu's (2014) research on form three students' information literacy competency through project work experience. The theory posits that students moved or progressed in one or more directions or approaches (Action \& product; Cognition; and Participation direction) of information literacy advancement while working on resource or information-based tasks.

\section{Problem Statement}

The Malaysian MOE anticipates that task-based learning assessment system will promote and inculcate critical and creative thinking skills or higher order thinking skills (HOTS) or KBAT (Kemahiran Berfikir Aras Tinggi), Kementerian Pelajaran Malaysia, (2006), and Kementerian Pendidikan Malaysia, 2014). However, until today, little is known on the contribution of PBL towards improving learning achievement through information literacy development. Little is known on the success of project works offered in lower secondary education towards producing information literate students as there are little-studies conducted on students' learning skills development through the projects, Yu (2014, Abdullah, (2008). This study therefore, aims to find out the answers.

\section{Research Objectives}

1. To understand how upper secondary students experience information literacy through resource-based projects.

2. To find out in which direction of the Three Directions Model have the students progressed?

\section{Literature Review}

IL is probably one of the most misunderstood or misinterpreted skills in the contemporary world, Jackson, (2006), McAdoo (2008). Lundh and Limberg (2008) conclude that the least that can be said about the concept is about "information seeking and use", two important elements recognized by all the scholars attempting to describe information literacy. Crucial to the more 
Vol. 7, No. 3, July 2018, E-ISSN: 2226-6348 @ 2018 HRMARS

recent information literacy definitions is the notion of how information literacy mastery is associated with learning process. Kuhlthau (2004) sees the concept of information literacy as evolving from the more traditional library skills, which emphasizes on the location of sources, and then shifts to information skills, which stresses on strategies to use information. Plotnick (2000) beautifully situates information literacy within school learning context; it reads: "it is a process, requiring subject content; it needs to be integrated with the school curriculum; it is vital to success in school and life" (p. 28).

In today's increasingly digitized environment, information literacy is also most commonly associated with ICT and research skills, or a combination of several learning skills. Thomas (2004) remind of the importance of educating school children on information literacy to help them to deal with a number of information-related issues such as; problems of information overload, inappropriate use of Internet material, failure to evaluate and synthesize information, and neglect of non-digital sources of information. Kuhlthau (2004) and Thomas (2004) highlight the need to properly educate information literacy to students, stressing that we need to teach them making sense of information, rather than pampering them by feeding them with pre-digested and carefully selected information. Other researchers (Breen, 2005; and Williams \& Wavell, 2006) are of the opinion that the best information literacy instruction is the one which is embedded within the context of course curricula, and not separated from it. Eisenberg \& Berkowitz (2006) and Kuhlthau (2004) insist that students learn information literacy by experiencing the learning process through guided and proper information process models, such as their Big6 and ISP information literacy models respectively.

A broad body of literature demonstrates that resource-based, problem-based, and project-based learning (PBL) improves student achievement, (Breen \& Fallon, 2005; Grant, 2002; Mokhtar \& Majid, 2006; Mondschein, 2007. It is generally understood that resource-based learning $(\mathrm{RBL})$ is an umbrella term consisting of detailed instructional methodologies such as inquiry-based learning, problem-based learning, and project-based learning. Lupton (2004) believes information literacy programmes should be able to create opportunities for self-directed and independent learning in which learners become engaged in using a wide variety of information sources to expand their knowledge, construct knowledge, ask informed questions, and sharpen their critical thinking".

Studies by Alexandersson and Limberg (2003) and Limberg (2007) reveal that school assignments, meant to educate students on information literacy are focusing too much on gathering facts rather than on deep learning. The prevalence of information gathering rather than information use instructions is also discussed in various other studies (Abdullah, 2008; Hart, 2000; Williams \& Wavell, 2006).

Researchers in the information literacy discipline (Breivik, 2005; Kuhlthau, 2004; Herring, 2011; Macklin, 2001) constantly associate RBL approach with information literacy development, arguing that both teachers and students need to have access to a rich variety of resources to facilitate learning. Meanwhile, (Breen \& Fallon, 2005; and Grant, 2002) claim RBL method also helps to accomplish both the subject content and information-literacy objectives through the 


\section{INTERNATIONAL JOURNAL OF ACADEMIC RESEARCH IN PROGRESSIVE EDUCATION AND}

DEVELOPMENT

Vol. 7, No. 3, July 2018, E-ISSN: 2226-6348 @ 2018 HRMARS

various learning activities and use of diverse learning materials. Nichols's (2009) 3 Directions Model explores students' experiences working with information through a research-based task. The model discloses three main approaches the students take towards these tasks, namely; (a) Actions and Product Direction: producing sub products or products; (b) Cognition Direction: learning about their subject; and (c) Participation Direction: participating in a scholarly or professional community. Any behaviour or action that the students undertake in completing their research paper could be placed on one, two, or all three directions, depending on the situation. The 3 approaches or directions in IL learning experience is presented in figure 1 below:

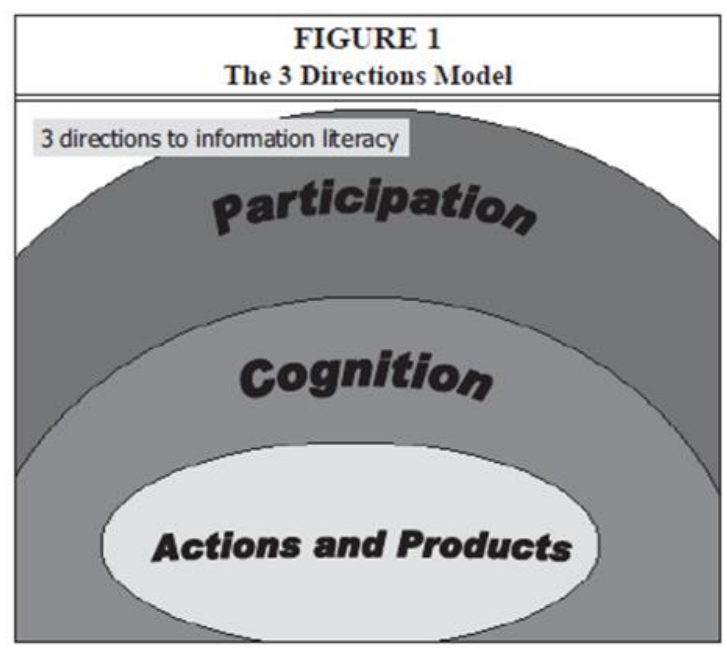

Figure 1 The 3 Directions Model (Source: Nichols, 2009)

While PBL is viewed as a good platform to teach information literacy, researchers are quick to warn that strong information literacy-supported school environment is important to develop the skills. The education system and the school curriculum should encourage cross- curricular skills development, Abdullah, 2008; Kong; 2008; Tan \& Theng, 2006. They caution that information literacy instruction across the curriculum goals needs to be carefully planned in order to achieve the desired goals (Abdullah, 2008; Hart, 2002; Mokhtar \& Majid,2006; Webber, 2000). (Kong; 2008; Tan \& Theng, 2006; Williams \& Wavell, 2006a) underpin the need to have a solid curriculum framework to equip students with the competencies to manage rapid development of resources in the information-rich digital society. Meanwhile, Tan and Theng, (2006) demonstrate that project work curriculums where information literacy models are embedded into them generate better quality learning output and higher learning achievement

\section{Methodology}

This research employed a qualitative case study design to examine how upper secondary students (grade 10) experience information literacy while working on project assignments. It also aims to understand in which direction of the Three Directions Model the students undertake in completing their project. Case study has been used for years in different types of research and across disciplines. The choice of adopting case study approach for this study is based on several careful considerations. The rich context and lack of control over the events in this research, which is a characteristic of case studies, render it the best method to choose. Yin (2003) alleges that 
Vol. 7, No. 3, July 2018, E-ISSN: 2226-6348 @ 2018 HRMARS

case studies are the preferred strategy when (a) "how" or "why" questions are being posed; (b) when the investigator has little control over events; and (c) when the focus is on a contemporary phenomenon within some real-life context, all of which are relevant to this study. The study also maps students' information literacy experiences to the Three Directions approaches to understand which information literacy path/s the students had followed in their research process.

The respondents in this study were carefully selected to ensure that they best represent the population, namely all upper secondary school students (form four and form five) in Malaysia. The study was a small scale research, and conducted at a limited time span, and only involving a group of seven students as the research respondents. All of them came from a school in Shah Alam, Selangor. As in most qualitative studies, a purposive sampling technique was employed. The criteria established in selecting the respondents are:

a) The school was a typical or mainstream school with average academic performance (representing the mainstream students)

b) The students were willing to participate, and at the time of the research, were at the upper secondary school level (to monitor how they have progressed in their information literacy and research skills after completing various project works at the lower secondary school level).

The data collection was conducted in April 2017. The researchers had to wait for several months before they were granted the permission to engage with the participants. The researchers had to go through three levels of research application process, namely: (a) the Educational Planning Research Department (EPRD), MOE: (b) Selangor State Educational Department (JPNS), and (c): School principal

Merriam (2009) reminds that in qualitative research, ethical issues are likely to emerge with regards to the collection of data and dissemination of findings. Hence, the researchers took the ethical issue seriously in planning and implementing the research. They addressed the ethical considerations in this study by:

a) Obtaining approval from the Educational Planning Research Department (EPRD), MOE, Selangor Educational Department (JPNS), and school principals before embarking on the research.

b) Communicating the objectives of the research clearly to each participant, both written and orally.

c) Getting the study participants signed a written consent form after informing them of the research. d) Taking steps to protect the privacy and confidentiality of the research participants.

e) Using coded references to protect the anonymity of the participants.

f) Seeking permission before data collection activities are audio/video recorded.

The data analysis in this study was carried out in two stages; primary and secondary data analysis. The primary data analysis began before conducting the fieldwork data collection. Interview process and research questions were studied in preparation for data collection. The researchers 
Vol. 7, No. 3, July 2018, E-ISSN: 2226-6348 @ 2018 HRMARS

had mentally focused on the research questions to guide them on being selective as to what to pay attention to during the interviews.

Data analysis also took place while transcribing the data from the recorded audiotapes. The researchers became to understand the data during the

transcribing process itself.

At the second stage of analysis, processed data (transcribed and selected data) were gathered and organized in electronic files and folders, ready for analysis. They were then tabulated in data analysis matrices using word processing and spreadsheet software. At this point, potential codes were generated, listed and tabulated according to the research objectives and research questions. The data were categorized according to these areas: (a) students' experience of information literacy through project work; and (b) Students' information literacy experiences mapped against the 3 Directions Model. The data from interview transcripts were thoroughly read several times before they were carefully coded. Initially, open coding was developed to categorize the data. Later, axial coding was developed to make connections between the various codes and to further subdivide the categories.

\section{Findings}

1. How upper secondary students experience information literacy

Task Definition:

Little data was collected from the students on how they started to plan their research project because they were asked to reflect on their general project work experiences. They had difficulty to reflect on the details of any particular project, such as how they refined their topic or how they made early research plans as they had worked on various different projects in the past. However, upon further probing, the students revealed that they tend to choose convenience topics, or topics that they can relate well as they found it is easier, compares to unfamiliar, or more challenging topics. An example is displayed through this dialogue: Niena: " I choose a topic that I can relate with". (to a question on how the students choose their project topic). The general finding shows that the students preferred to the most convenient way to work on their project, including choosing easy topics to work on, and did not have high curiosity to explore more challenging tasks to develop themselves further.

Information seeking and Information location and access:

Not surprisingly, all of the students in this study admitted to start their information seeking activities with the Internet. "The Internet!...." that was their response when they were asked on how they started their information seeking activities. A student, Ishak, explained that most of the information for his research came from the Internet and he only sought for more information from other sources when he wanted in-depth information that was not available in the Internet. He added that the public library provided good resources but it was quite far and rather inconvenience for them as they did not have the transportation to go there. The students admitted that they did not use the school library as it did not provide the resources they were looking for. They also justified that the Internet was their preferred information source as it was 
INTERNATIONAL JOURNAL OF ACADEMIC RESEARCH IN PROGRESSIVE EDUCATION AND DEVELOPMENT

Vol. 7, No. 3, July 2018, E-ISSN: 2226-6348 @ 2018 HRMARS

the most convenience information source to access information. A student, Hakeem, added that today, most people have smart phones with access to the internet, and that was the most convenient tool to look for information any time they wanted to. The findings also show that the students did not put much effort identifying the range of sources to use for their project as they had already decided to use the Internet from the beginning of their research.

When it comes to the Internet information seeking strategies, it quickly becomes evident that the students were only employing the basic "one keyword" searching strategy with no problem accessing the information they needed. Feeling accomplished in their successful information seeking, they did not feel the need to try out more sophisticated advance search strategies. For instance, Sam proudly announced "I just Google, and all the information appears...."

Their simple project topics had made it so easy for the students to get abundance of information from the Internet without being challenged to try out more advance search strategies. In the area of selecting information for access, the students were not particularly concerned about selecting quality information from the free web. Although they claimed that they did select information from before accessing them, closer examination reveals that their information selecting criteria were not those that information professionals have recommended. These are how the students select their information for access:

Sabreena: "normally (I choose) those (information/websites) at the top"

Niena: "hmm...l will check the website...l will not choose those with too many advertisements"

Naja: "I will read all the information, then I will choose those that are really related to my topic"

Based on the students' responses, they did not mention the criteria that reflect the quality of information such as the reputation of the author, the reliability of the information source, or the timeliness of the information in selecting information. These findings indicate that although the students were independent and confident information seekers, they did not consider the recommended criteria in selecting information from the Internet such as the authority, reliability, validity, and currency of the information.

Information use and Information synthesis:

All of the students appeared confident on how to proceed with their task after accessing their information. They explained that they worked on their project mostly on their own, after the school hours, and with little supervision from the teacher. This indicates that they were independent learners who were able to take control of their own learning. This includes taking steps such as evaluate, extract, and interpret information from the various sources for the report writing task. Not much information was acquired from the students on how they performed the above activities as they were discussing their general project experiences, rather than focusing on the detail processes of a single project. Nevertheless, the findings indicate that although the 


\section{INTERNATIONAL JOURNAL OF ACADEMIC RESEARCH IN PROGRESSIVE EDUCATION AND DEVELOPMENT}

Vol. 7, No. 3, July 2018, E-ISSN: 2226-6348 @ 2018 HRMARS

students were independent enough to work on their own, they were not aware of the various issues pertaining to information literacy competencies in information use. One good example is their limited awareness of the ethical use of information issue. Although the students had some idea about what plagiarism is, (they likened it to the "copy and paste" act) their awareness level was still low. While most of the students declared that they tried to avoid plagiarizing "because it is not our work", they admitted to have plagiarized from Internet articles at one time or another, citing that some teachers didn't even check if they were plagiarizing. With regards to using information from the Internet, the students admitted to simply extract all the information without giving due credit to the original authors. This indicates that they had lower awareness to properly cite, or to give the credit to the original authors compares to the plagiarism issue.

\section{Evaluation:}

Findings from this study show that the students were focusing on the end product of their project, rather than on their learning experiences. Regardless, the students also expressed to have developed learning in three broad areas, namely: (a) creative and critical thinking skills; (b) work process/learning skills; and (c) interpersonal and social skills. Although the students have never referred to any information literacy models to guide them with good research practice, they nonetheless were able to manage research work, made decisions, and solved problems in challenging situations. They were also able to document their research process into project reports. Although limited was discussed on the students' learning skills development, and evidences also points to students' poor learning skills mastery, the students still demonstrated high confidence level of their learning skills. They specifically confided to continue developing these learning skills every time they worked on new assignments: information seeking skills, ICT skills (computer uses skills), and writing skills. Despite the fact that their work was more inclined to the "gathering and compiling" type of work rather than real research work, they still engaged in numerous challenges that calls for creative and critical thinking, employing various learning skills. Last but not least, the students form strong collaboration with one another, as well as with others who can help them to make their task easier.

2. Students' information literacy direction mapped against the Three Directions Model:

With regards to the Three Directions (SIL) model, the students demonstrated improved understanding in all three (Action \& Product, Cognition, and Participation) directions, although there are still a lot of rooms for improvement.

While little data was acquired on the students' information literacy engagement in the $A \& P$ direction in the current study, the A\&P orientation trend is nonetheless evident as the students' discussions were mostly revolving around the need to be compliant to the project guideline to produce the expected result. The students were notably progressing well in the cognition direction where they personally believed that they have become competent and independent learners and were able to go through all the different research stages with little supervision from their teachers as detailed above. Lastly, the students also progressed in the participation direction where they reflected to improve their social and interpersonal skill through their project experiences (although this was not part of their learning goal at the beginning of their project journey). The students related to have developed better understanding on their research areas 
Vol. 7, No. 3, July 2018, E-ISSN: 2226-6348 @ 2018 HRMARS

and learning skills through extended circle of friends and acquaintances that were formed in the pursuit of their research journey. Among others, they sought information from beyond classroom friends, such as from friends in other schools, tuition friends, and also from new connections that they have discovered in the social media. They also approached more knowledgeable adults such as resource persons and professionals such as librarians to get primary data. However, it is noted that, while the students were active seeking information from extended parties who were from outside of their circle of friends, they were just passive information users. They sought for information from others but they rarely shared the information they had with others. There were little incidences where they related to share their project knowledge experience with junior school mates or younger siblings who were working on project work. None of the students also shared their research experiences with others in social media.

To conclude, findings from this study suggest that the students have developed better understanding in their subject areas as well as acquired basic learning skills through their project work experiences. However, the students still lacked fine and delicate skills in finding, accessing, selecting, filtering, evaluating, ethically using, and synthesizing information, as they were not assisted by any information literacy models or research frameworks to work on their project. The students were being detached from any information literacy literature which could assist them to work systematically according to globally recognized standards. This has greatly hindered full learning potential among the students to develop their information literacy competencies.

\section{Discussion}

Although the students' research process in this study may not entirely conforming to recognized information literacy frameworks, their experiences working on various projects has significantly contributed to their increased knowledge and learning skills development. They have become familiar with research work after spending three years working on history and geography projects in their lower secondary education years. They demonstrated greater confidence in the use of ICT and critical thinking, and the findings also show that their knowledge in ethical use of information has improved compares to the findings of an earlier study by Yu (2014). Yu reported that the students in lower secondary education had limited knowledge on ethical use of information and were not sure of what plagiarism was. The prevalence and intensity of the plagiarism problem has also decreased based on what was reported in previous study. The earlier study found that the students were plagiarizing indiscriminately as they were not aware it was a wrong practice. This shows learning advancement by the students in the upper secondary school who developed better knowledge and learning competencies compares to those in the lower secondary grades due to repeated exposure on research or project work. The students in this study had confided learning progression in three main areas namely; (a) creative and critical thinking skills, (b) research process/learning competencies, and (c) interpersonal/social skills. This is consistent with the findings by $(\mathrm{Yu}, 2014)$ that reports lower secondary school students had progressed in three areas from their project experience, namely; (a) the topic and research area, (b) work process and learning skills, and (c) interpersonal and social skills through their project work experiences. 


\section{INTERNATIONAL JOURNAL OF ACADEMIC RESEARCH IN PROGRESSIVE EDUCATION AND}

DEVELOPMENT

Vol. 7, No. 3, July 2018, E-ISSN: 2226-6348 @ 2018 HRMARS

Numerous studies (Grant, 2002; Mokhtar \& Majid, 2006; Mondschein, 2007) also discussed the promising potential of project-based learning (PBL) in engaging students in meaningful learning that benefit the students not only in the subject area, but also in developing multiple learning skills and interpersonal skills through collaborative work with peers (Mokhtar \& Majid, 2006; Nichols, 2009; Webber, 2000). Despite the highlighted potential of PBL for information literacy education, Kong; 2008; Tan \& Theng, 2006; Williams \& Wavell, 2006 have highlighted the need to first clearly introduce the skill in the school curriculum to create better awareness of the skills before we can expect the skills to be incorporated into learning tasks. Scholars such as Kong; 2008; Tan \& Theng, 2006) also emphasize the need to clearly incorporate information literacy models into learning instructions as guidelines for teachers and students to refer to. The students in this study had worked on various projects without being assisted by any information literacy models. They were detached from important literature to guide and to correct them whenever they had problems. This explains the students' poor understanding of information literacy, indifferent attitude about selecting quality information, low awareness of ethical use of information, and uninterested mindset to become more creative and critical learners. The students had no idea about the standard of the work they have produced as they had no access to any information literacy literature. Tan \& Theng, (2006) have demonstrated the importance of introducing clear information literacy guideline to assist learning by proving that students who work on project with clear information literacy guidance yield more meaningful learning experience and accomplished better quality learning products.

Similarly, the Situated Cognition theoretical lens through the Three Directions (SIL) Model also records learning development among the students in all three directions.

While little data was acquired on the students' information literacy engagement in the $A \& P$ direction, the students' strong concern on their learning product suggest their inclination towards this direction. Findings from earlier study Yu (2014) also shows that Malaysian students are inclined to be product-oriented, rather than focusing on their research process (process oriented). The students in this study also progressed in the cognition direction. They claimed that they have become increasingly familiar with research work. They have become better information seekers, readers, information users, researchers, and better writers through their repeated project experience. They voiced out their confidence in working independently on other project assignments in the future. This reflects growing engagement and ease with research work. In the Participation Direction, the students related how they grew in knowledge and maturity as a result of improved inter personal skills which they developed through collaborating practices. Throughout the whole project duration, the students collaborated with one another. They taught, shared, and learned various tips and strategies. This had exposed them to new knowledge and skills which they could not have otherwise, picked up on their own. Most importantly, they were introduced to a

bigger circle of scholars such as other supportive teachers (besides the project teacher), more senior friends, resourceful family members and other adults in the community (college students, librarians). 
INTERNATIONAL JOURNAL OF ACADEMIC RESEARCH IN PROGRESSIVE EDUCATION AND DEVELOPMENT

Vol. 7, No. 3, July 2018, E-ISSN: 2226-6348 @ 2018 HRMARS

\section{Conclusion}

Despite some challenges and drawbacks in the project implementation which has limited full learning potential, the students have nevertheless, grown to become better information seekers, readers, information users, researchers, and better writers. This is a good indication that the students have progressed in knowledge and research skills. However, information literacy models/ instructions need to be clearly incorporated into project work instructions to help the students to benchmark their work to internationally accepted standards. Having been detached from important information literacy literature has resulted in the students' poor awareness and poor information literacy mastery. In addition to it, the higher authority should also review project work curriculums where the learning tasks need to be designed to be more complex and ill-structured to challenge the students to engage in more difficult learning situations. The revised project work curriculum should include selected information literacy models or frameworks to provide systematic assistance to both teachers and students. It is hoped that these findings could improve the students' learning quality which will transform to improved learning achievements. It can be concluded that PBL significantly contributes towards students' higher order thinking skills(HOTS) as well as the broader information literacy skills.

\section{References}

Abdullah, A. (2008). Building an information literate school community: approaches to inculcate information literacy in secondary school students. Journal of Information Literacy, 2(2).

Alexandersson, M., \& Limberg, L. (2003). Constructing meaning through information artefacts. The New Review of Information Behaviour Research, 4, 17-30.

Breen, E. \& Fallon, H. (2005). Developing Student Information Literacy to Support Project and Problem-based Learning. Handbook of enquiry \& problem-based learning, 179-188. Retrieved Mac 312008 from http://www.nuigalway.ie/celt/pblbook/chapter17.pdf

Breivik, P.S. (2005). 21st century learning and information literacy. Change, 37(2), 20-27.

Chan, F.M. (2002). Developing information literacy in the Malaysian Smart Schools: Resourcebased learning as a tool to prepare today's students for tomorrow's society. School Libraries for a Knowledge Society: Proceedings of the 31st Annual Conference of the International Association of School Librianship and the sixth International Forum on Research in School Librarianship. Petaling Jaya, Malaysia (pp.203-215).

Chen, C. L., Yan, R, Huang, T. 2014. The Effect of Inquiry Based integrated Information Literacy Instruction: Four Year Trends. Journal of Education Media \& Library Sciences. Vol.51, no.4: 561-595. Available at: $\underline{\text { http://jomls.tku..edu.tw. }}$

Eisenberg M. \& Berkowitz, B. (2006).The Big6: Information litracy for the information age. Retrieved 17 June 2008 from http://www.big6.com/ 
INTERNATIONAL JOURNAL OF ACADEMIC RESEARCH IN PROGRESSIVE EDUCATION AND

DEVELOPMENT

Vol. 7, No. 3, July 2018, E-ISSN: 2226-6348 @ 2018 HRMARS

Grant, M.M. (2002). Getting a grip on project-based learning: theory, cases and recommendations. Meridian, 5(1).

Hart, G. (2000). Project work as a vehicle for information literacy education in a circuit of South African primary schools. Paper presented at the Proceedings of the 66th IFLA Council and General Conference, Jerusalem, Israel 13-18 August 2000. Retrieved on 7 August 2009 from http://ifla.queenslibrary.org/IV/ifla66/papers/074-133e.htm

Jackson, C. M. (2006). The High School Library Web Site: Scaffolding Information Literacy Skills. PhD thesis, Illinois State University, Illinois.

Kementerian Pendidikan Malaysia, Bahagian Pembangunan Kurikulum, (2014). Kemahiran Berfikir Aras Tinggi Aplikasi di Sekolah. Retrieved from https://www.moe.gov.my/images/WargaKPM/Guru/kbat/EBOOK.pdf on 20th December, 2017.

Kementerian Pelajaran Malaysia (2006b). Rancangan Malaysia ke 9: Plan Induk Pembangunan Pendidikan, 2006-2010. Bahagian Perancangan dan Penyelidikan Dasar Pendidikan Kementerian Pelajaran Malaysia.

Kementerian Pendidikan Malaysia. (2002). Buku Panduan Kajian Sejarah Tempatan Sekolah Menengah Rendah.Pusat Perkembangan Kurikulum.

Kong, S.C. (2008). A curriculum framework for implementing information technology in school education to foster information literacy.Computers \& Education,51, 129-141.

Kuhlthau, C. C. (2004). Seeking Meaning: A Process Approach to Library and Information Services (2nd Eds.). Norwood, New Jersey: Ablex Publishing Corp.

Limberg, L. (2007). Learning assignment as task in information seeking research. Information Research, 12(1).

McAdoo, M.L. (2008). A Case Study of Faculty Perceptions of Information Literacy And Its Integration into the Curriculum. PhD thesis Indiana University of Pennsylvania.

Mokhtar, I. A., \& Majid, S. (2006). Information literacy education in the context of project work: Application of multiple intelligences and mediated learning. Paper presented at the Proceedings of the Asia-Pacific Conference on Library \& Information Education \& Practice 2006 (A-LIEP 2006) Singapore.

Mondschein, H. (2007). Problem-Based Learning As A Method for Teaching Information Literacy to First Year Students. PhD thesis, California Lutheran University, California. 
Vol. 7, No. 3, July 2018, E-ISSN: 2226-6348 @ 2018 HRMARS

Montgomery, P. (1997). Use of information: The information Literacy Phenomenon. In A.E. Tepe \& J. Calarco (Eds.). A Handbook for Pathways to Knowledge. I. F. S. Follett's Information Skills Model. McHenry: 8-10.

Nichols, J.T. (2009). The 3 Directions: Situated Information Literacy. College \& Research Libraries, 70(6), 515-530.

Ott, L.F., (2015). Attitudes of secondary teachers towards project based learning: A phenomenology. Doctoral dissertation, Capella, University.

Plotnick, E. (2000). Definitions/Perspectives. Teacher Librarian, 28, 27-29.

Tan, M.H.M., \& Theng, Y.L. (2006). Building information literacy through project work: A case study in Singapore. Paper presented at the Proceedings of the Asia-Pacific Conference on Library \& Information Education \& Practice 2006 (A-LIEP 2006), Singapore.

Thomas, N.P. (2004). Information Literacy and Information Skills Instruction: Applying Research to Practice in the School Library Media Center. Westport CT: Libraries Unlimited.

Webber, S. \& Johnston, B. (2000).Conceptions of information literacy: new perspectives and implications. Journal of information science 26(6), 381-397.

Williams, D. \& Wavell, C.(2006a). Information literacy in the classroom: Secondary school teacher's conceptions. Final report on research funded by Society for Educational Studies. Research Report 15. The Robert Gordon University.

Yin, R.K. (2003). Case study research; Design and methods (3rd. Ed.). Thousand Oaks, CA: Sage.

$\mathrm{Yu}, \mathrm{H}$. (2014). Conception, integration, and experiences of information literacy through resourcebased learning. Unpublished PhD thesis, University of Malaya, Kuala Lumpur.

Yu, H., Noordin, S. A., Mokhtar, S. A, \& Abrizah, A. (2011). Integrating Information literacy instruction (ILI) through resource-based school projects: An interpretive exploration. Education for Information, 28(2-4), 247-268. 